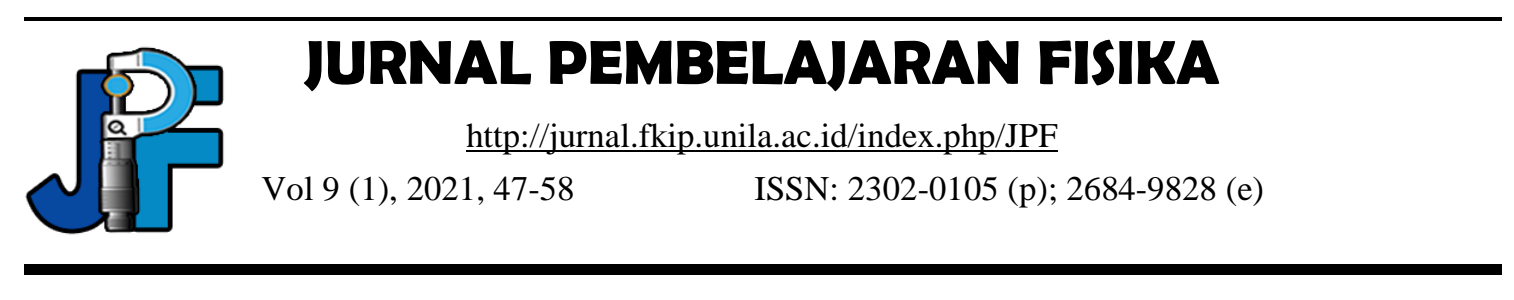

\title{
The Effectiveness of PBL Assisted by EBM to Increase Students' Conceptual Understanding
}

\author{
Yustinus Maksimilianus Dhey Nesi*, Endang Purwaningsih \\ Postgraduate Physics Education, State University of Malang, Indonesia \\ *e-mail: justinlannesi@gmail.com
}

Received: May 25, 2021

Accepted: June 31, 2021

Published: July 19, 2021

\begin{abstract}
Conceptual understanding involves students' abilities in the aspects of translation, interpretation, and extrapolation. A way to increase conceptual understanding is to use excelbased modeling (EBM). However, the use of excel-based modeling (EBM) has not been applied in physics learning at the junior high school level. This study aims to test the effectiveness of project-based learning assisted by excel-based modeling to increase students' conceptual understanding of wave material. The sample of this study were students of class VIII-1 junior high school who were selected using the purposive sampling technique. This study used a onegroup pretest-posttest design. Research data determine the effectiveness of using excel-based modeling using a pretest and posttest in the form of 7 identical essay questions. The data obtained were analyzed using a paired-sample T-test. After the treatment, data on the increase in the value of each indicator of concept understanding were obtained, namely 91.18 (translation), 86.65 (interpretation), and 83.09 (extrapolation). In the end, excel-based modeling is quite effective in improving students' understanding of concepts.
\end{abstract}

Keywords: Conceptual Understanding, Excel-based Modelling, Project-based Learning

DOI: http://dx.doi.org/10.23960/jpf.v9.n1.202105 


\section{INTRODUCTION}

Science learning should send students to the mastery of science concepts and their application in real life (Istiadah et al., 2016). The learning process is an important process that must not be passed. Observation of the processes that occur in nature is an important part of learning science (Merritt et al., 2018). Science learning is the acquisition of knowledge as well as the process itself (Nugraha, 2018). It must involve observation, data collection, questioning, scientific explanation and communication (Merritt et al., 2018). Important aspects of science learning include instructional learning that supports data-based reasoning and arguments (Piaw \& Don, 2014), data analysis and its application in real life (Farrokhnia et al., 2019). This learning aspect helps students understand the concept of science so that in the end students are able to achieve learning goals (Barak \& Yuan, 2021) and there is a process of transfer of knowledge (Farrokhnia et al., 2019).

$21^{\text {st }}$ century learning emphasizes the importance of providing opportunities for students to think and act like a scientist in a project-based learning model (PBL) (Ricaurte \& Viloria, 2020). PBL is one of the learning models used during the online learning process because it is able to create meaningful learning for students (Barak \& Yuan, 2021; Tinenti, 2018). It improves students' thinking skills and cooperation in solving problems (Guo et al., 2020; Masrifah et al., 2020). Students' problem-solving abilities provide knowledge of the consequences of what students know (predict) (Bakhtiari et al., 2020). This ability will ultimately improve students' conceptual understanding (Kollmer et al., 2021).

Conceptual understanding involves meaningful and in-depth learning (Farrokhnia et al., 2019). Meaningful learning can be explained as understanding content and processes by structuring students' new ideas (Rattan, 2018) which is elaborated with the previous knowledge obtained by students (Farrokhnia et al., 2019). The process of storing knowledge facts (Shapiro et al., 2017) and critical thinking (Andayani et al., 2018) is a sign of students experiencing meaningful learning. Meaningful learning helps students connect the knowledge gained into life experiences (deep learning) (Farrokhnia et al., 2019; Mills, 2016). Conceptual understanding includes 3 indicators, namely the ability to change general knowledge content with own thoughts (translation) (Farrokhnia et al., 2019; Shapiro et al., 2017), the ability to understand ideas obtained from the learning process and try to connect new ideas with previous knowledge through basing on evidence and principles found in the learning process (extrapolation) (Farrokhnia et al., 2019) and the ability to interpret the acquired knowledge into the real world (interpretation) (Dahlstrom-Hakki et al., 2020; Farrokhnia et al., 2019; Gruver, 2018; Mills, 2016).

The use of a project-based learning model must be supported by the other learning methods, one of which is the use of an excel-based modeling (Bermúdez et al., 2020; Grigore \& Barna, 2015; Uddin et al., 2017). The use of Microsoft Excel (Uddin et al., 2017) in learning physics has not been optimal in improving students' conceptual understanding. The use of excel as a technological tool is often tested in physics learning, especially in the concept of waves (Uddin et al., 2017) and motion (Grigore \& Barna, 2015). However, it needs to be underlined is the importance of using 2 different classes in this trial, class $\mathrm{A}$ as the experimental class and the other class as the 
traditional class (Uddin et al., 2017). In addition, it is important to measure students' interest in physics by using excel-based modelling (Bermúdez et al., 2020) by optimizing the pretest and posttest (Malone et al., 2018). However, the use of excelbased modelling is still limited in learning physics, especially for junior high school students.

The use of excel-based modeling in project-based learning has been widely researched (Bermúdez et al., 2020; Grigore \& Barna, 2015; Uddin et al., 2017). Use of excel-based modeling (Uddin et al., 2017) Excel learning has not been optimal in improving students' conceptual understanding of waves (Uddin et al., 2017) and motion (Grigore \& Barna, 2015). The important thing in excel-based modeling is the use of 2 different classes, class A as an experimental class and another class as a traditional class (Uddin et al., 2017). In the learning process, students' interests and emotions (Liaw et al., 2020) towards excel-based modeling is very important to measure (Uddin et al., 2017) by optimizing the pretest and posttest (Malone et al., 2018).

Excel-based modeling that is developed by students not only provides expertise but also experience (Frownfelter- Lohrke, 2017). Excel-based modeling is a model developed based on Microsoft Excel (Sahni \& Pikal, 2017). Excel software provides worksheets that contain data (in the form of numbers) that can be manipulated (Brown et al., 2014) and calculated (Beare, 2013). Transverse wave images can also be created using Excel. Students are able to see and analyze the relationship between wave frequency, time, amplitude, and phase difference using excel-based modeling developed by students. This is able to minimize student misconceptions (Kabil, 2015) because excel-based modeling helps students to understand the concept of waves.

Based on previous researchs (Bermúdez et al., 2020; Grigore \& Barna, 2015; Lehmann et al., 2019), it is necessary to conduct research on how the role of using excel-based modeling in understanding student concepts. Therefore, the purpose of this study is to test the effectiveness of using excel-based modeling on students' understanding of concepts.

\section{METHOD}

This research was conducted in one of the junior high schools in Ende regency in the even semester of 2021. This study aims to test the effectiveness of excel-based modeling to improve students' understanding of concepts. This research is an experimental study with sample selection using purposive sampling technique.

\section{Research Design \& Procedures}

This study used a one group pretest-posttest design. The pretest was given at the beginning of the action before the research treatment was held. After that, the researcher carried out experimental research by applying project-based learning assisted by excelbased modeling. At the end of the lesson, the researcher carried out a posttest to determine the effectiveness of excel-based modeling in learning. Learning is carried out online using google meet and WhatsApp. 


\section{Population and Sample}

The population of this study were 8 grade students of one of the junior high schools in Ende regency, totaling 7 classes. Of the 7 classes, the researcher chose 1 class as the research sample, namely class of VIII-1. The research sample was selected using purposive sampling technique. The sample was chosen because class of VIII-1 was a class that mastered the excel application and its application in mathematical calculations.

\section{Data Collection and Instrument}

The research instrument used was the pretest and posttest questions in the form of 7 identical questions. These questions had been validated by an expert before used in research. These questions are used to measure students' conceptual understanding which include translation, interpretation, and extrapolation with a Cronbach Alpha value is 0,898 . The realm of conceptual understanding for each question can be seen in Table 1 .

Table 1. Realm of Conceptual Understanding

\begin{tabular}{cc}
\hline Realm of Conceptual Understanding & Question Number \\
\hline Translation & 1,7 \\
\hline Interpretation & $3,4,5$ \\
\hline Extrapolation & 2,6 \\
\hline
\end{tabular}

\section{Data Analysis}

The effectiveness of excel-based modeling is measured using normalized gain (N-gain). The $\mathrm{N}$-gain value is calculated using a formula:

$$
N-\text { gain }=\frac{\text { Posttest score }- \text { Pretest Score }}{\text { Ideal Score }- \text { Pretest score }}
$$

Samples are normally distributed before determining the effectiveness of using excelbased modeling in learning with paired-sample $\mathrm{T}$ test analysis. If sig. (2-tailed) $<0,05$, there are differences between pretest and posttest score. If sig. (2-tailed) $>0,05$, there are no differences between pretest and posttest score.

\section{RESULT AND DISCUSSION}

Before treatment, students complete the pretest. The average value of students' conceptual understanding can be seen in Figure 1. This value represents the average value of students' conceptual understanding before the treatment (pretest) and after treatment of learning using excel-based modeling (posttest). Figure 1 shows an increase in students' conceptual understanding before treatment and after treatment. 


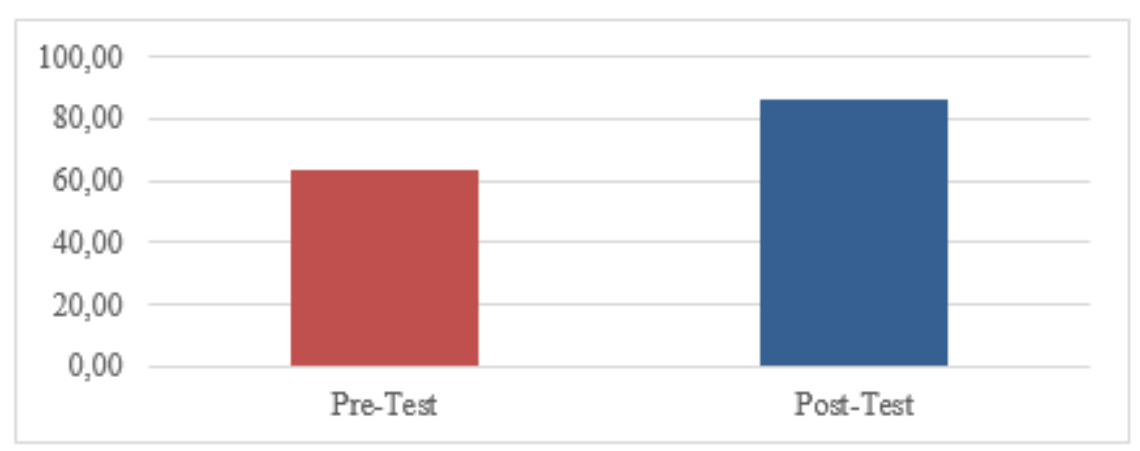

Figure 1. The Average Value of Students' Conceptual Understanding

The average value of the conceptual understanding indicator can be seen in Figure 2. Based on Figure 2, it is known that the highest average value of the conceptual understanding indicator is the translation, which is 91.18 . The lowest average value of the conceptual understanding indicator is the extrapolation of 83.09. This shows that the use of excel-based modeling can improve students' ability to understand the concepts (Malone et al., 2018) of vibrations and waves which are expressed in other ways than what students have already known (Uddin et al., 2017).

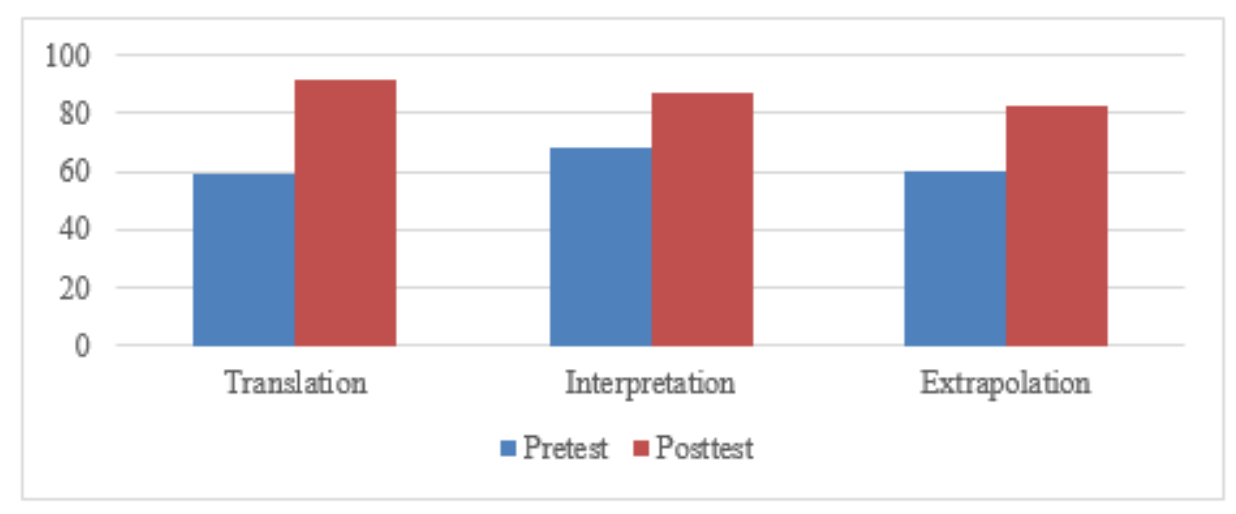

Figure 2. The Average Value of the Conceptual Understanding Indicator

The research data that had been normally distributed were then analyzed using the $\mathrm{T}$ test. The $\mathrm{T}$ test result data can be seen in Table 2 below.

Table 2. Paired-Sample T Test

\begin{tabular}{|c|c|c|c|c|c|c|c|c|c|}
\hline \multicolumn{10}{|c|}{ Paired Samples Test } \\
\hline & & \multicolumn{5}{|c|}{ Paired Differences } & \multirow[b]{3}{*}{$t$} & \multirow[b]{3}{*}{$\mathrm{df}$} & \multirow{3}{*}{$\begin{array}{l}\text { Sig. (2- } \\
\text { tailed) }\end{array}$} \\
\hline & & \multirow[b]{2}{*}{ Mean } & \multirow{2}{*}{$\begin{array}{c}\text { Std. } \\
\text { Deviation }\end{array}$} & \multirow{2}{*}{$\begin{array}{l}\text { Std. } \\
\text { Error } \\
\text { Mean }\end{array}$} & \multicolumn{2}{|c|}{$\begin{array}{l}95 \% \text { Confidence } \\
\text { Interval of the } \\
\text { Difference }\end{array}$} & & & \\
\hline & & & & & Lower & Upper & & & \\
\hline Pair 1 & $\begin{array}{l}\text { Nilai Pre- } \\
\text { test - } \\
\text { Nilai } \\
\text { Post-test }\end{array}$ & $-22,412$ & 2,776 & 0,476 & $-23,380$ & $-21,443$ & $-47,082$ & 33 & 0,000 \\
\hline
\end{tabular}


Table 2 shows that the sig. (2-tailed) $<0.05$ with a significance of $5 \%$. This means that there are differences in students' pretest and posttest scores, so it can be concluded that there is an effect of learning using excel-based modeling on students' conceptual understanding. However, the average $\mathrm{N}$-gain score shows 0.65 (medium category). This shows that learning using excel-based modeling is quite effective in increasing students' conceptual understanding.

Excel-based modeling is a representation model that is able to improve conceptual understanding through images and simulations (Uddin et al., 2017). Excelbased modeling is able to develop process and problem-solving abilities (Sahni \& Pikal, 2017). Process and problem-solving skills are acquired by students through projectbased learning. Project-based learning with excel-based modeling is able to develop students' representational abilities. Students make a wave representation model using Ms. Excel. The representation model developed by the students contains the amount of time, position, frequency, amplitude, and phase difference of the wave. These quantities are then linked to the mathematical equation of the wave, namely $Y=A \sin \left(\frac{2 \pi f t}{360}+\frac{2 \pi \theta}{360}\right)$. By making this representation model, students are able to explain the effect of frequency and amplitude on the resulting waves. This can be seen in Figure 3.

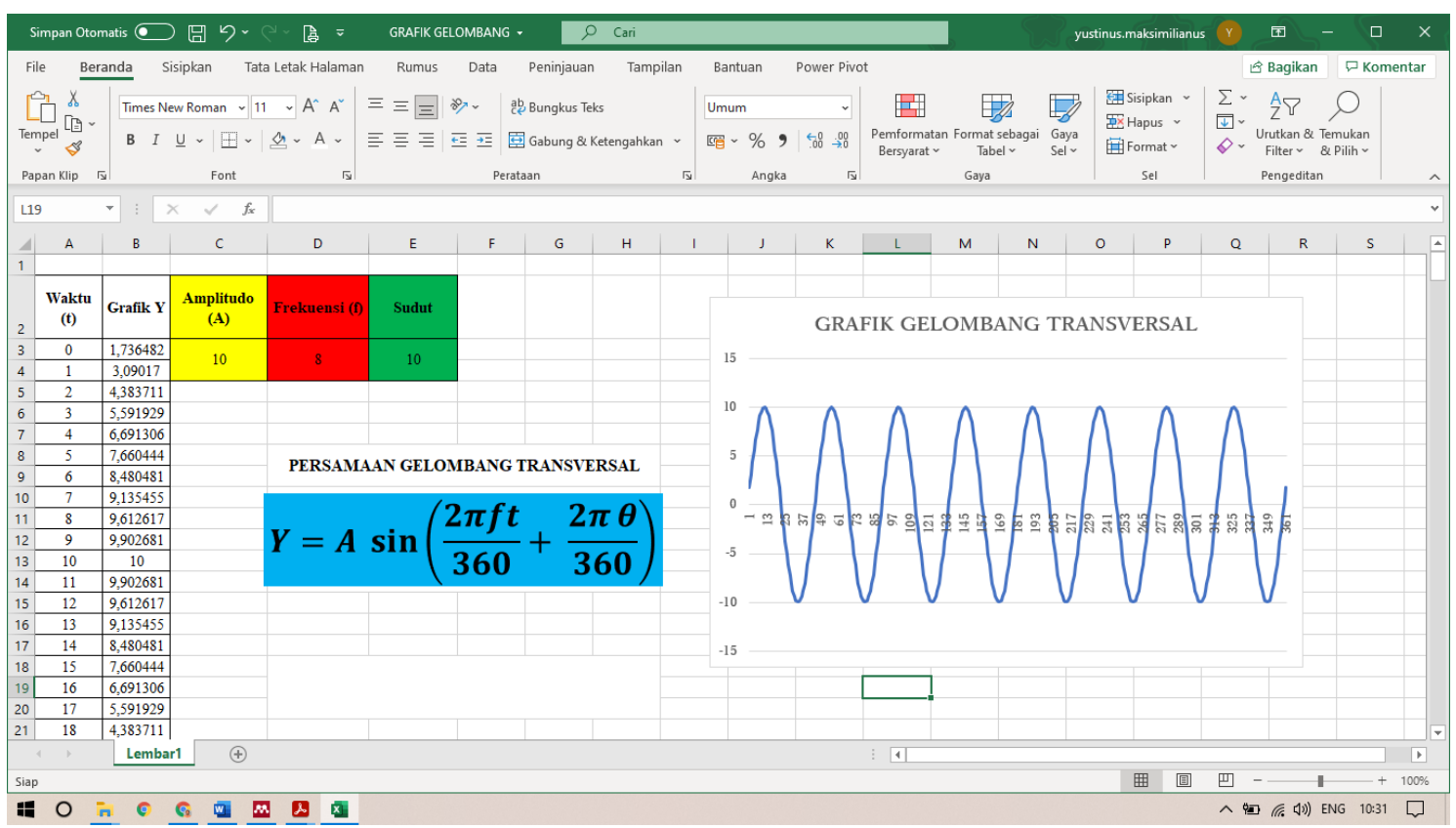

Figure 3. Excel-based Modelling

Project-based learning assited by excel-based modeling is quite effective in increasing students' conceptual understanding. Students work in groups in the process of learning. Each group worked on a project task in the form of making an excel-based modeling representation. Work on the excel-based modeling representation model is done together in groups and students also get help from ICT teachers in developing and writing excel formulas. The results of the excel-based modeling representation model are then written on the student activity sheets and communicated in the class. 
The three indicators of conceptual understanding can be found in the results of student worksheet reports and students' posttest answers. One student wrote that the effect of amplitude on waves lies in the wave height (peak). On the other hand, frequency affects the number of waves produced. The above statement was put forward by students from the results of the excel-based learning representation model created by students. This indicates that there are 2 indicators of understanding the concepts used by students, namely translation and extrapolation. This can be seen in Figure 4.

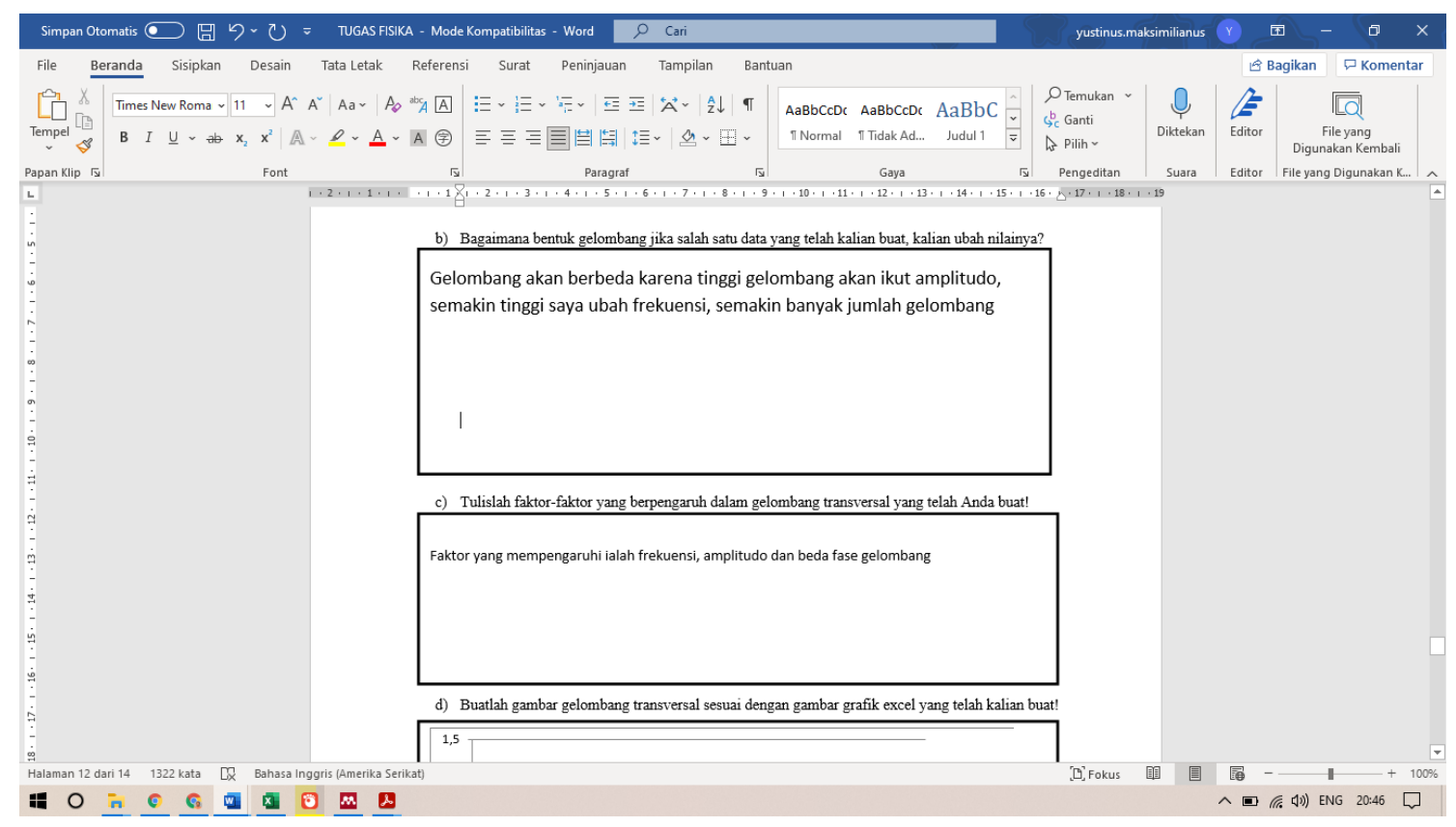

Figure 4. Student's Answer

Before the treatment, students have already known that frequency affects the high and low sound and the effect of amplitude on the strength of the sound but do not know the effect of frequency and amplitude on the number of waves and waveforms. Figure 4 shows students' ability to express the concept of the influence of frequency and amplitude of waves using their own language (translation). The aspect of translation in Figure 2 above appears when students already have basic knowledge (Bartell et al., 2013; Shapiro et al., 2017) and students develop previously acquired knowledge using language that is simpler and easier for them to understand. The language used by students is a description of their conceptual understanding and their way of thinking (Bartell et al., 2013). The description and way of thinking are obtained from the excelbased learning representation model created by students. The representational model of excel-based learning is used as a tool in understanding knowledge about waves. The knowledge that students get from the excel-based modeling model created is the result of students' findings (in the form of evidence and principles) in the learning process (extrapolation). This knowledge is then developed as a conceptual understanding of the wave material.

The interpretation aspect is found in the students' posttest answers as seen in Figure 5 (answer number 5). The questions given are about the application of waves in everyday life. Students predict the types of waves that occur due to a drum membrane 
being hit. This question is an application of the interpretation aspect. Interpretation is an indicator of conceptual understanding that requires students to interpret the knowledge gained to phenomena that occur in life (Dahlstrom-Hakki et al., 2020; Farrokhnia et al., 2019; Gruver, 2018).

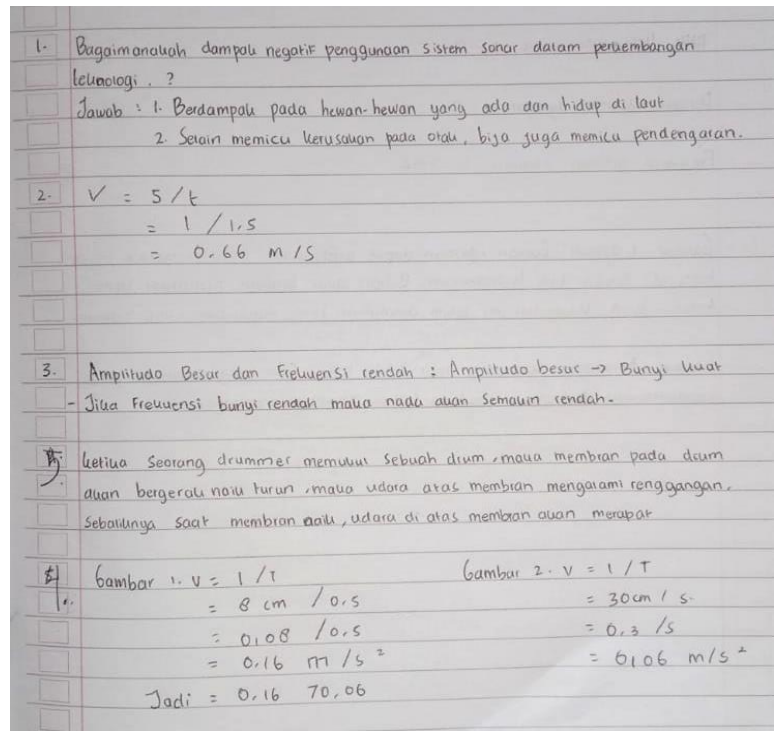

Figure 5. Student's Posttest Answer

Based on Figure 5, the indicator of the highest concept understanding is the translation aspect. The translation aspect has an average posttest score of 91.18. The translational aspect gets the highest average score because students are able to speak the concept of waves in language that is commonly used and easily understood by the students themselves. Students construct their own understanding of the concept of waves by using sentences that are simpler and easier to understand (Syahidi \& Fartina, 2020). The sentences used to construct his knowledge are the result of the knowledge he has acquired and discovered in the learning process. Therefore, it is important for students to have the right initial knowledge so that misconceptions do not occur (Fulmer, 2013). Basic knowledge is obtained by students from student interaction in the learning process so that students can construct their knowledge into visual forms in the form of graphics and pictures or in the form of mathematical equations (Bartell et al., 2013). After creating an excel-based modeling representation, students can draw conclusions based on the data and evidence they find (Brown et al., 2014) and improve conceptual understanding (Derman \& Ebenezer, 2020) on wave material.

The indicator of conceptual understanding in the extrapolation aspect is the lowest aspect with an average value of 83.09. This is because students have not been able to create new ideas found in the process of completing the excel-based modeling representation model. The inability of these students was due to during the learning process, especially in group work in completing (Amamou \& Cheniti-Belcadhi, 2018) the excel-based modeling model project, there were still some students who were not involved in the process (Fatmala et al., 2020) of completing the representation model. As a result, there were still students who answered posttest questions by following other students' answers. 


\section{CONCLUSION}

The results of the paired-sample $T$ test showed that there were differences in the posttest and pretest scores on students' conceptual understanding questions. This means that there is a difference in the average of students' conceptual understanding before and after learning using excel-based modeling. Project-based learning assisted by excelbased learning is able to improve students' understanding of concepts in translation, extrapolation and interpretation in the moderate category. The $\mathrm{N}$-gain results showed that learning using excel-based modeling was quite effective in improving students' conceptual understanding of wave material. So, further research needs to be done to test the effectiveness of using excel-based modeling in improving conceptual understanding, especially in the aspect of extrapolation.

\section{REFERENCES}

Amamou, S., \& Cheniti-Belcadhi, L. (2018). Tutoring in Project-Based Learning. Procedia Computer Science, 126, 176-185. https://doi.org/10.1016/j.procS.2018.07.221

Andayani, Y., Hadisaputra, S., \& Hasnawati, H. (2018). Analysis of the Level of Conceptual Understanding. Journal of Physics: Conference Series, 1095(1). https://doi.org/10.1088/1742-6596/1095/1/012045

Bakhtiari, Z., van Ditmarsch, H., \& Rivieccio, U. (2020). Bilattice logic of epistemic actions and knowledge. Annals of Pure and Applied Logic, 171(6), 102790. https://doi.org/10.1016/j.apal.2020.102790

Barak, M., \& Yuan, S. (2021). A cultural perspective to project-based learning and the cultivation of innovative thinking. Thinking Skills and Creativity, 39(September 2020), 100766. https://doi.org/10.1016/j.tsc.2020.100766

Bartell, T. G., Webel, C., Bowen, B., \& Dyson, N. (2013). Prospective teacher learning: Recognizing evidence of conceptual understanding. Journal of Mathematics Teacher Education, 16(1), 57-79. https://doi.org/10.1007/s10857-012-9205-4

Beare, R. (2013). A System to Exploit The Spreadsheet "Excel" For Enhancing Learning In Science. Journal of Chemical Information and Modeling, 53(9), 1689-1699.

Bermúdez, M., Puertas, J., \& Cea, L. (2020). Introducing Excel spreadsheet calculations and numerical simulations with professional software into an undergraduate hydraulic engineering course. Computer Applications in Engineering Education, 28(1), 193-206. https://doi.org/10.1002/cae.22185

Brown, S., Hutton, B., Clifford, T., Coyle, D., Grima, D., Wells, G., \& Cameron, C. (2014). A microsoft-excel-based tool for running and critically appraising network meta-analyses-an overview and application of NetMetaXL. Systematic Reviews, 3(1), 1-11. https://doi.org/10.1186/2046-4053-3-110

Dahlstrom-Hakki, I., Alstad, Z., \& Banerjee, M. (2020). Comparing synchronous and asynchronous online discussions for students with disabilities: The impact of 
social presence. Computers and Education, 150(June 2019), 103842. https://doi.org/10.1016/j.compedu.2020.103842

Derman, A., \& Ebenezer, J. (2020). The Effect of Multiple Representations of Physical and Chemical Changes on the Development of Primary Pre-service Teachers Cognitive Structures. Research in Science Education, 50(4), 1575-1601. https://doi.org/10.1007/s11165-018-9744-5

Farrokhnia, M., Pijeira-Díaz, H. J., Noroozi, O., \& Hatami, J. (2019). Computersupported collaborative concept mapping: The effects of different instructional designs on conceptual understanding and knowledge co-construction. Computers and Education, 142(July). https://doi.org/10.1016/j.compedu.2019.103640

Fatmala, F. D., Suyanto, E., Wahyudi, I., \& Herlina, K. (2020). The Effect of GIL Assisted Phyphox in Physics Learning towards Creative Thinking. Jurnal Pembelajaran Fisika, 8(2), 141-150.

Frownfelter- Lohrke, C. (2017). Teaching good Excel design and skills: A three spreadsheet assignment project. Journal of Accounting Education, 39, 68-83. https://doi.org/10.1016/j.jaccedu.2016.12.001

Fulmer, G. W. (2013). Constraints on Conceptual Change: How Elementary Teachers' Attitudes and Understanding of Conceptual Change Relate to Changes in Students' Conceptions. Journal of Science Teacher Education, 24(7), 12191236. https://doi.org/10.1007/s10972-013-9334-3

Grigore, I., \& Barna, E. S. (2015). Using Excel Spreadsheets to Study the Vertical Motion in A Gravitational Field. Procedia - Social and Behavioral Sciences, 191, 2769-2775. https://doi.org/10.1016/j.sbspro.2015.04.259

Gruver, J. (2018). A trajectory for developing conceptual understanding of logarithmic relationships. Journal of Mathematical Behavior, 50(January), 1-22. https://doi.org/10.1016/j.jmathb.2017.12.003

Guo, P., Saab, N., Post, L. S., \& Admiraal, W. (2020). A review of project-based learning in higher education: Student outcomes and measures. International Journal of Educational Research, 102(April), 101586. https://doi.org/10.1016/j.ijer.2020.101586

Istiadah, L., Yuliati, L., \& Zubaidah, S. (2016). Penguasaan konsep gerak pada siswa SMP. January, 1006-1013.

Kabil, O. (2015). Philosophy in Physics Education. Procedia - Social and Behavioral Sciences, 197(February), 675-679. https://doi.org/10.1016/j.sbspro.2015.07.057

Kollmer, J., Hosp, T., Glogger-Frey, I., Renkl, A., \& Eitel, A. (2021). Adjunct aids and signals support online learning from multiple representations. Journal of Computer Assisted Learning, 37(1), 172-182. https://doi.org/10.1111/jcal.12477

Lehmann, J. A. M., Hamm, V., \& Seufert, T. (2019). The influence of background music on learners with varying extraversion: Seductive detail or beneficial effect? Applied Cognitive Psychology, 33(1), 85-94. https://doi.org/10.1002/acp.3509 
Liaw, H., Yu, Y. R., Chou, C. C., \& Chiu, M. H. (2020). Relationships between Facial Expressions, Prior Knowledge, and Multiple Representations: a Case of Conceptual Change for Kinematics Instruction. Journal of Science Education and Technology, Ml. https://doi.org/10.1007/s10956-020-09863-3

Malone, K. L., Schunn, C. D., \& Schuchardt, A. M. (2018). Improving Conceptual Understanding and Representation Skills Through Excel-Based Modeling. Journal of Science Education and Technology, 27(1), 30-44. https://doi.org/10.1007/s10956-017-9706-0

Masrifah, M., Setiawan, A., Sinaga, P., \& Setiawan, W. (2020). An Investigation of Physics Teachers' Multiple Representation Ability on Newton's Law Concept. Jurnal Penelitian \& Pengembangan Pendidikan Fisika, 6(1), 105-112. https://doi.org/10.21009/1.06112

Merritt, E. G., Chiu, J., Peters-Burton, E., \& Bell, R. (2018). Teachers' Integration of Scientific and Engineering Practices in Primary Classrooms. Research in Science Education, 48(6), 1321-1337. https://doi.org/10.1007/s11165-016-96040

Mills, S. (2016). Conceptual understanding: A concept analysis. Qualitative Report, 21(3), 546-557. https://doi.org/10.46743/2160-3715/2016.2308

Nugraha, W. S. (2018). Peningkatan Kemampuan Berpikir Kritis Dan Penguasaan Konsep Ipa Siswa Sd Dengan Menggunakan Model Problem Based Learning. EduHumaniora | Jurnal Pendidikan Dasar Kampus Cibiru, 10(2), 115. https://doi.org/10.17509/eh.v10i2.11907

Piaw, C. Y., \& Don, Z. M. (2014). Predictors of Multiple Intelligence Abilities for Malaysian School Leaders. Procedia - Social and Behavioral Sciences, 116, 5164-5168. https://doi.org/10.1016/j.sbspro.2014.01.1093

Rattan, G. (2018). Disagreement and Conceptual Understanding. Theoria (Sweden), 84(2), 179-210. https://doi.org/10.1111/theo.12150

Ricaurte, M., \& Viloria, A. (2020). Project-based learning as a strategy for multi-level training applied to undergraduate engineering students. Education for Chemical Engineers, 33, 102-111. https://doi.org/10.1016/j.ece.2020.09.001

Sahni, E. K., \& Pikal, M. J. (2017). Modeling the Secondary Drying Stage of Freeze Drying: Development and Validation of an Excel-Based Model. Journal of Pharmaceutical Sciences, 106(3), 779-791. https://doi.org/10.1016/j.xphs.2016.10.024

Shapiro, A. M., Sims-Knight, J., O’Rielly, G. V., Capaldo, P., Pedlow, T., Gordon, L., \& Monteiro, K. (2017). Clickers can promote fact retention but impede conceptual understanding: The effect of the interaction between clicker use and pedagogy on learning. Computers and Education, 111, 44-59. https://doi.org/10.1016/j.compedu.2017.03.017

Syahidi, K., \& Fartina. (2020). The Effectivness of Problem Based Learning Teaching Model to Increase Students' Rational Thinking Skills. Jurnal Pembelajaran Fisika, 8(1), 87-93. 
Tinenti, Y. R. (2018). Model Pembelajaran Berbasis Proyek (PBP) dan Penerapannya Dalam Proses Pembelajaran di Kelas (Pertama, Issue September). Penerbit Deepublish.

https://www.researchgate.net/publication/327892325_Model_Pembelajaran_Ber basis_Proyek_dan_Penerapannya_Dalam_Proses_Pembelajaran_di_Kelas

Uddin, Z., Ahsanuddin, M., \& Khan, D. A. (2017). Teaching physics using Microsoft Excel. Physics Education, 52(5). https://doi.org/10.1088/1361-6552/aa7919 